\title{
Ex situ conservation of three Himalayan ferns through hydroponic culture under Greenhouse conditions
}

\author{
Cyaria Gurung ${ }^{1}$ and Anirudra Gurung ${ }^{2}$ \\ ${ }^{1}$ Corresponding author: Department of Botany, Siliguri College, Siliguri - 734 001, Dist. Darjeeling, West \\ Bengal, India. E-mail: gurungcyaria@gmail.com \\ ${ }^{2}$ Department of Botany, St. Joseph's College, P.O. North Point, Darjeeling - 734 104, West Bengal, India
}

[Received 17.09.2019; Revised 05.12.2019; Accepted 06.12.2019; Published 31.12.2019]

\begin{abstract}
The ex situ conservation of three sub-Himalayan ferns, namely, Microsorum membranaceum (D. Don) Ching, Asplenium nidus L. and Nephrolepisexaltata (L.) Schott were studied through hydroponic culture.

The study revealed that successful cultivation by root dipping technique and culture medium are greatly influenced by the availability of nutrients, light, temperature, $\mathrm{pH}$ of the nutrient medium and available oxygen. The nutrient uptake in hydroponics was largely controlled by the $\mathrm{pH}$ of the medium. Best growth of seedlings was observed with a half-strength Hoagland solution with $\mathrm{pH} 5.8-6.5$ in hydroponics and at $\mathrm{pH}$ of $6.0-6.5$ in soil systems. However, the mature plants could be grown at a slightly higher $\mathrm{pH}$ range of $5.8-8.5$.

There is distinct differences in their plant vigour root morpho-anatomy, rachis length, size and number of the fronds, pigment contents etc in conventionally and hydroponically grown ferns. Plants in hydroponics showed more luxuriant and faster growth and delayed appearance of reproductive structures that could be directly co-related with optimal nutrient uptake in hydroponics and nutrient stress in soil systems. Findings of hydroponics is promising and can be recommended as an alternative to soil based ex situ cultivation and conservation of various ferns under greenhouse conditions.
\end{abstract}

Key words: Ferns, Hydroponics, ex situ conservation, Root dipping technique, Pot culture

\section{INTRODUCTION}

The diversity of plant life is facing serious threats, largely due to habitat loss, habitat degradation and increasing exploitation of natural resources. A large percentage $(30-40 \%)$ of the global flora has been estimated to be under threat for extinction (Raven 1999; Manickam 1995). The decline in the area, number and quality of habitats is mainly attributed to encroaching urbanization, growing industrialization, intensive farming and unsustainable harvesting of wild species (Marimuthu \&Manickam 2011). Therefore, there is an urgent need for conservation of plants like ferns many of which are facing serious threats for extinction. Application of latest biotechnological techniques like tissue culture (Fay 1994; Johnson 2003; Nair 2000), in vitro spore germination have been used by some workers for certain species of ferns for propagation and ex situ conservation (Sara 2001; Manickam et al. 2003; Johnson et al. 2005, 2008; Sara \& Manickam 2005, 2007; Johnson \& Manickam 2006, 2007). Ex situ measures are widely recognized today as effective tools for fern preservation, complementary to in situ conservation programmes and need further exploitation.

While conserving species in situ is the ideal system, it cannot always be ensured. As a result, ex situ conservation methods can play a very important and complementary role in 
ensuring the survival of these species, by providing a back-up of genetic resources of not only the populations in the wild but also some rapidly disappearing ferns of ornamental values (Marimuthu \& Manickam 2011; Manickam 1995). Many authors have reported the medicinal uses and ornamental values of various species of ferns in the past, while some have recently reported the heavy metal absorbent capacity of these plants. But no substantial work has been done with regard to the hydroponic cultivation and their ex situ conservation through hydroponic cultivation. Therefore, the present study was undertaken to explore the potential of hydroponic cultivation in ex situ conservation and attempts were made to successfully grow three different ferns in a medium free of soil particles and acclimatize the mature plants to grow hydroponically.

\section{MATERIALS AND METHODS}

\section{Plant Materials used:}

Live seedlings and mature plants of Microsorum membranaceum (D. Don) Ching, Asplenium nidus L. and Nephrolepis exaltata (L.) Schott were taken as plant materials for the present study. These were collected from their natural habitats in sub-Himalayan Darjeeling Hills and were maintained on forest-floor humus in earthen pots. The voucher specimens of the plants used in the present study have been deposited in the herbarium of North Bengal University (NBU), Siliguri, Dist. Darjeeling.

\section{Chemicals Used:}

The chemicals used in the present investigation included ammonium dihydrogen phosphate, $\mathrm{KNO}_{3}, \mathrm{Ca}\left(\mathrm{NO}_{3}\right)_{2}, \mathrm{MgSO}_{4}, \mathrm{EDTA}, \mathrm{KOH}, \mathrm{FeSO}_{4} .7 \mathrm{H}_{2} \mathrm{O}$, Iron tartarate, $\mathrm{H}_{3} \mathrm{BO}_{3}$, $\mathrm{MnCl}_{2} \cdot 4 \mathrm{H}_{2} \mathrm{O}, \mathrm{ZnSO}_{4} \cdot 7 \mathrm{H}_{2} \mathrm{O}, \mathrm{CuSO}_{4} \cdot 5 \mathrm{H}_{2} \mathrm{O}, \mathrm{H}_{2} \mathrm{MbO}_{4} \cdot \mathrm{H}_{2} \mathrm{O}, \mathrm{N}: \mathrm{P}: \mathrm{K}(19: 19: 19), \mathrm{N}: \mathrm{P}: \mathrm{K}$ $(20: 20: 20)$,commercially available plant feed and freshly prepared half strength Hoagland Solution (Hoagland \& Arnon 1950).

Plants were treated with different chemical solutions $(1-3 \mathrm{mM})$ for seedlings and 5 $25 \mathrm{mM}$ for mature plants to test the efficacy of these nutrient solutions on promoting plant growth and development. The frequency and volume of the nutrient solution applied were varied depending on the type of substrates (sand, perlite, agronet dust), stage of maturity of plants, the size of the container, irrigation systems used and the prevailing climatic conditions. Plants were fed daily with nutrient solutions both in continuous and intermittent modes. Under no circumstances the plants were allowed to suffer from water stress, as this was found to directly affect their overall performance and acclimatization in hydroponic culture chamber and their subsequent ex situ conservation.

\section{Methodology}

This study was conducted primarily through qualitative (physiological, morphological and anatomical analysis) and quantitative (measurements of plant vigour, measurement of pigment content, proline content etc.) research methods using standard techniques.

\section{Biochemical analysis:}

\section{Extraction and Estimation of Chlorophyll:}

For extraction, $1 \mathrm{~g}$ of plant tissue was extracted in $80 \%$ acetone and the final volume was made up to $25 \mathrm{ml}$ with $80 \%$ acetone (Harbone 1973). For estimation, the extract was measured at O.D. values of 645 and $663 \mathrm{~nm}$ (Arnon 1949) and chlorophyll 'a', chlorophyll ' $b$ ' and total chlorophyll contents were calculated using the following formulae: 


$$
\begin{aligned}
& \text { Total chlorophyll }=\left(20.2 \times \mathrm{A}_{645}+8.02 \times \mathrm{A}_{663}\right)_{\mathrm{mg}} / \mathrm{g} \text { fresh weight } \\
& \mathrm{Ch} l_{\mathrm{a}}=\left(12.7 \times \mathrm{A}_{663}-2.69 \times \mathrm{A}_{645}\right) \mathrm{mg} / \mathrm{g} \text { fresh weight } \\
& \mathrm{Chl}_{\mathrm{b}}=\left(22.7 \times \mathrm{A}_{645}-4.68 \times \mathrm{A}_{663}\right) \mathrm{mg} / \mathrm{g} \text { fresh weight }
\end{aligned}
$$

\section{Extraction and Estimation of Carotenoid Content:}

For extraction, $1 \mathrm{~g}$ of plant tissue was extracted in $80 \%$ methanol and the final volume was made up to $10 \mathrm{ml}$ with $80 \%$ methanol (Lichtenthaler 1987).

For estimation, the O.D. was measured at $480 \mathrm{~nm}, 645 \mathrm{~nm}$ and $663 \mathrm{~nm}$ and carotenoid content was calculated by using the following formula:

$$
\text { Carotenoid content }=\mathrm{A}_{480}-\left(0.114 \times \mathrm{A}_{663}\right)-0.638 \times \mathrm{A}_{645} \mu \mathrm{g} / \mathrm{g} \text { plant tissue }
$$

\section{Extraction and estimation of free proline}

\section{Extraction}

For the extraction of free proline the method of Bates et al. (1973) was followed. $1 \mathrm{~g}$ of plant tissue was crushed with $5 \mathrm{ml}$ of $3 \%$ sulfosalicylic acid in mortar with pestle. The slurry was filtered through Whatman No.1 filter paper at room temperature in dark condition. The supernatant was collected and stored at $4^{\circ} \mathrm{C}$ for further analysis.

\section{Estimation}

Proline content of the extract was estimated as described by Bates et al. (1973) with some modification. To $1 \mathrm{ml}$ of extract, $3 \mathrm{ml}$ of distilled water and $1 \mathrm{ml}$ of Ninhydrin solution $(2 \mathrm{~g}$ in $50 \mathrm{ml}$ of acetone and water mixture) were added. Then the mixtures were kept on a boiling water bath for 15 minutes. After cooling, the reaction mixture was poured in a separating funnel and $5 \mathrm{ml}$ of toluene was added and shaken vigorously. Lower colored layer was taken and optical density values (absorbance) were measured at $520 \mathrm{~nm}$.Quantification was done from a standard curve of proline.

\section{Hydroponic technique followed:}

Liquid Hydroponics: Thismethod as suggested by Sardare and Admane (2013) were followed in the present study. Seedlings were grown in solution culture with their roots suspended directly in a nutrient solution in culture tubes for variable period of time. Noncirculating methods such as Root dipping technique and Floating technique were used in the present investigation for various trials. The nutrient solutions used were changed either after five days or seven days after close monitoring of the condition of roots and solutions used.

Media Culture Technique: The media culture experiments were carried out in the present study using glass cage and opaque pots. All the media culture methods used had a solid medium for the roots such as sand, perlite, gravel or agronet dust.

Growing Medium: The growing medium used in the present study was an inert medium which did not provide any nutrients to the plant. It only provided the basis for the roots to grow in and allowed us to add the correct amount of nutrients and also monitor the $\mathrm{pH}$ in a hydroponic system. Coconut fibres, jute fibre, Perlite, Sand, Gravel and Agronet dusts were the various types of growing media used in the present study for growing plants hydroponically in Green Houses for successful cultivation and ex situ conservation.

Temperature: Temperature and wind or air movement is known to have a dramatic influence on the plants' consumption of water particularly when combined with high temperature. 

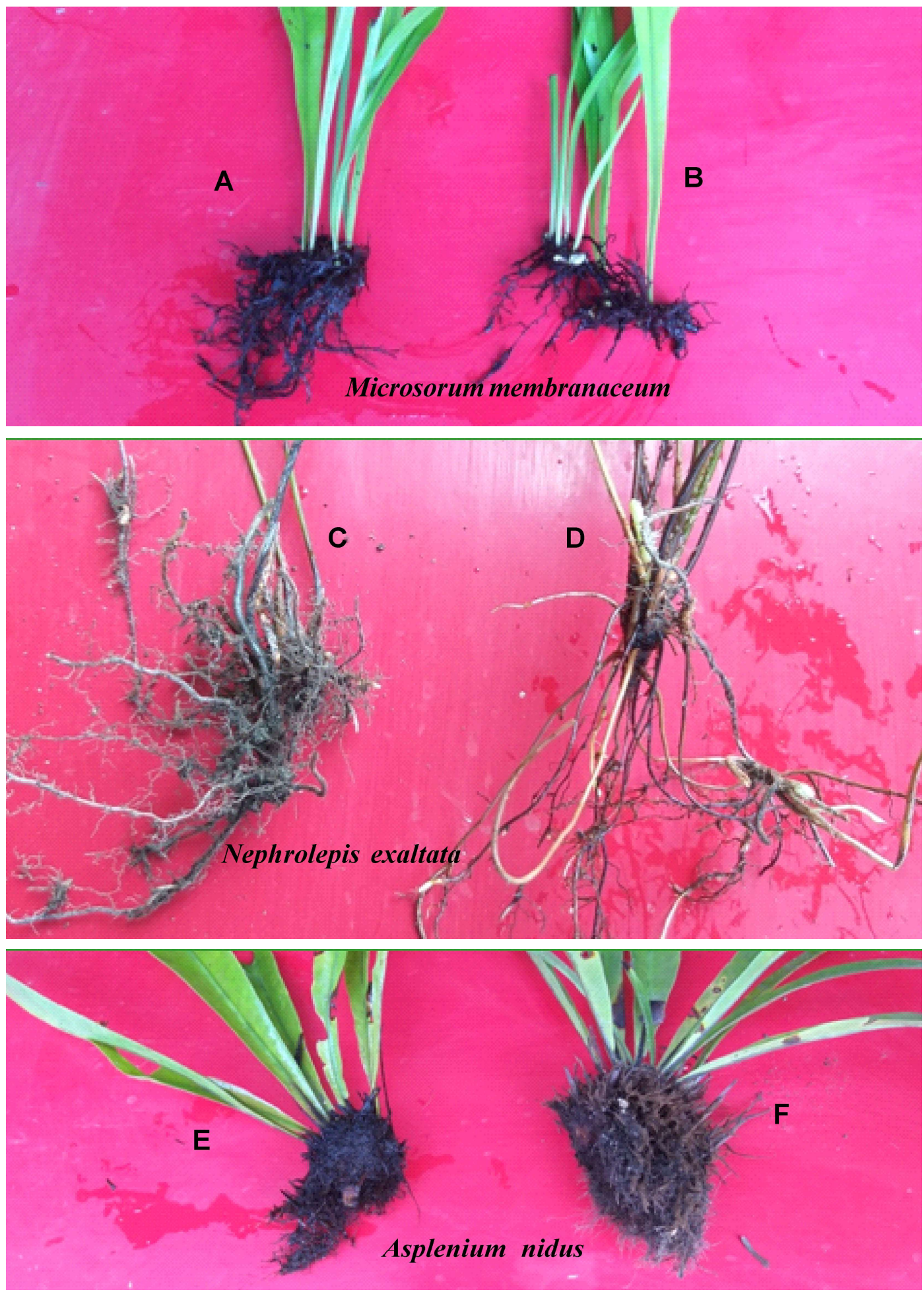

PLATE - I: Comparative root morphology of Soil grown (A, C \& E) and Hydroponically grown (B, D \& F) plants 
High temperatures tend to accelerate the growth of the plant which increases the plants' need for water. High temperatures also increase the plant's consumption of water for cooling itself through evaporation. Therefore, the ferns in the present study were grown in Green Houses in a moderate temperature range of $25-32^{\circ} \mathrm{C}$.

Water: The present study involved the use of soft water with calcium containing nutrients having a total salt concentration of less than $300 \mathrm{ppm}$. [The use of tap water was avoided as that may contain harmful contaminants and high salt concentrations which can adversely affect plant growth.] Whenever required, water was purified by distillation or reverse osmosis.

Light: The ferns used in the study were grown in Green Houses in pots using natural sunlight. But, whenever the need was felt for the use artificial lights, specially while growing indoors in glass cages and portable systems, LED (Light Emitting Diode) Grow Lights used for Hydroponic Gardens were used for their efficiency in promoting plant growth, zero toxicity and low cost of maintenance.

pH: All test plants in the present study were found to grow best at a $\mathrm{pH}$ range of 5.6-6.6 possibly, due to the availability of almost all nutrients from the nutrient solutions at this $\mathrm{pH}$ range. $\mathrm{pH}$ control was found to be an absolute necessity especially in case of static culture experiments, where there was no provision for replenishing the nutrients frequently.

Oxygen Level: For optimum growth of the seedlings and plants, the supply of sufficient oxygen from the rooting medium for the root respiration was found to be very critical. In nutrient culture experiments, especially root dipping method, the demand for oxygen was found to increase with increasing submergence of roots. Hence an oxygen pump commonly used in glass aquarium was used to provide continuous supply of oxygen to the respiring roots. Addition of open-structured materials like perlite was found to greatly reduce aeration stress and hence was used generously in pot culture experiments.

\section{RESULTS AND DISCUSSION}

The findings from the hydroponic culture experiments under Greenhouse conditions in the present study were found to be very encouraging. All test plants of Microsorum membranaceum, Asplenium nidus and Nephrolepis exaltata taken as test plants are known to grow epiphytically and not known to have any hydrophytic adaptations. But these ferns could be induced to grow hydroponically in glass chambers and opaque pots under green house conditions with a great degree of success for their ex situ conservation. Marimuthu \& Manickam (2011) have also earlier reported the use of in vitro spore culture technique for ex situ conservation of some threatened ferns from Western Ghats which further support our findings of ex situ conservation. The soil grown and hydroponically grown plants showed distinct differences in their mean rachis length, number of fronds and length of fronds (Table 1), root morphology and anatomy. Hydroponically grown plants showed a more luxuriant and faster growth rate of above ground parts than the soil grown plants. However, there was a marked difference in root morphology which showed profuse development of root hairs in soil culture and weak development of root and root hairs in hydroponics (Plate 1) which may be due to the aquatic adaptation of these ferns.

The anatomical differences between soil grown plants and hydroponically grown plants were very much evident in the present study. In case of root, vascular cambium was found to produce proportionately less secondary vascular tissues than the plants grown in soil. Secondary growth was also noticed in case of petiole but the amount of secondary xylem and phloem in contrast was comparatively much lesser in hydroponics. The length of the petiole in hydroponics was however found to be greater than the soil grown plants. The 

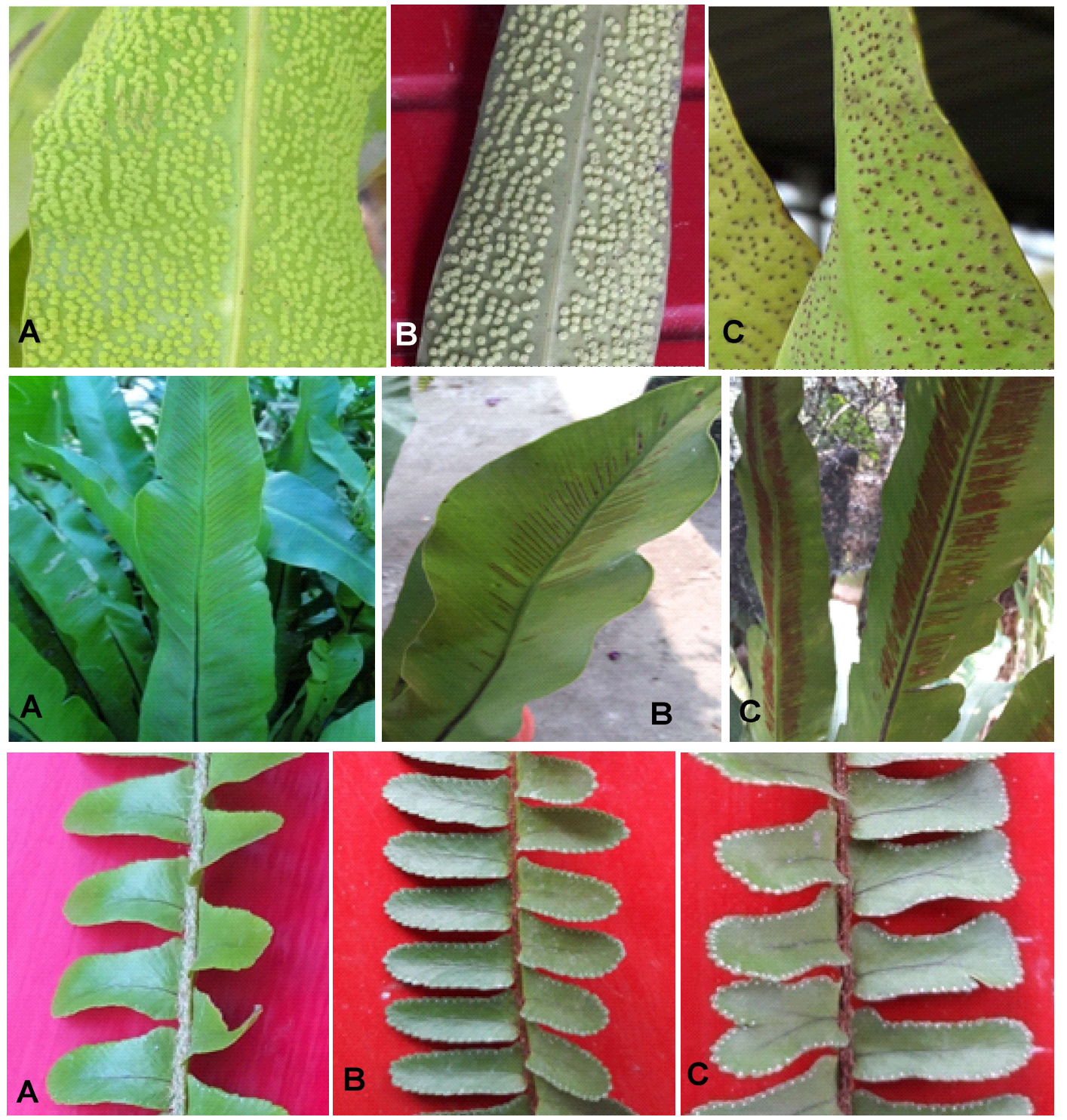

PLATE - II. Microsorum membranaceum (top row), Asplenium nidus (middle row) and Nephrolepis exaltata (lower row): Initiation of spore formatio and maturity in hydroponically (A \& B) and soil (C) grown plants.

amount of metaxylem and vessel diameter in hydroponically grown plants was also much lesser which may be due to easy availability and access to water. There was also marked difference in stellar arrangement between hydroponically and soil grown plants.

The hydroponically grown plants were found to contain comparatively much higher chlorophyll (Table 2) and carotenoid pigment contents (Table 3). But, interestingly, the spore development including onset of spore formation and maturity was found to be greatly delayed in hydroponically grown plants than in soil grown plants in all three tested fern species (Plate 2 ). This may be due to availability of optimal nutrients in hydroponics and nutrient stress in soil grown plants. This nutrient stress faced by soil grown plants could be further supported 
222 Ex situ conservation of three Himalayan ferns

Table 1.Comparative analysis of mean rachis length, number of fronds and length of fronds of soil grown and hydroponically grown ferns

\begin{tabular}{|l|c|c|c|c|c|c|}
\hline \multirow{2}{*}{ Name of Plants } & \multicolumn{2}{|c|}{$\begin{array}{c}\text { Chlorophyll a } \\
\text { (mg/g fresh wt.) }\end{array}$} & \multicolumn{2}{c|}{$\begin{array}{c}\text { Chlorophyll b } \\
\text { (mg/g fresh wt.) }\end{array}$} & \multicolumn{2}{c|}{$\begin{array}{c}\text { Total Chlorophyll } \\
\text { (mg/g fresh wt.) }\end{array}$} \\
\cline { 2 - 7 } & $\begin{array}{c}\text { Soil } \\
\text { Culture }\end{array}$ & $\begin{array}{c}\text { Hydro. } \\
\text { Culture }\end{array}$ & $\begin{array}{c}\text { Soil } \\
\text { Culture }\end{array}$ & $\begin{array}{c}\text { Hydro. } \\
\text { Culture }\end{array}$ & $\begin{array}{c}\text { Soil } \\
\text { Culture }\end{array}$ & $\begin{array}{c}\text { Hydro. } \\
\text { Culture }\end{array}$ \\
\hline $\begin{array}{l}\text { Microsorum } \\
\text { membranaceum }\end{array}$ & $8.14 \pm 0.8$ & $12.40 \pm 0.6$ & $10.06 \pm 0.3$ & $11.80 \pm 0.7$ & $18.20 \pm 0.5$ & $24.20 \pm 0.3$ \\
\hline Asplenium nidus & $10.42 \pm 0.5$ & $14.90 \pm 0.7$ & $5.49 \pm 1.3$ & $5.50 \pm 0.9$ & $15.91 \pm 1.4$ & $20.40 \pm 0.9$ \\
\hline Nephrolepis exaltata & $6.07 \pm 1.6$ & $7.82 \pm 0.9$ & $7.94 \pm 0.1$ & $13.88 \pm 1.4$ & $14.01 \pm 0.9$ & $21.70 \pm 1.6$ \\
\hline Results are average of 10 replicates & \multicolumn{7}{|l|}{} \\
\hline
\end{tabular}

Table 2. Comparative analysis of chlorophyll contents (Harbone 1973; Arnon 1949) of fertile leaf of soil grown and hydroponically grown ferns

\begin{tabular}{|l|c|c|c|c|c|c|}
\hline \multirow{2}{*}{ Name of Plants } & \multicolumn{2}{c|}{$\begin{array}{c}\text { Chlorophyll a } \\
\text { (mg/g fresh wt.) }\end{array}$} & \multicolumn{2}{c|}{$\begin{array}{c}\text { Chlorophyll b } \\
\text { (mg/g fresh wt.) }\end{array}$} & \multicolumn{2}{c|}{$\begin{array}{c}\text { Total Chlorophyll } \\
\text { (mg/g fresh wt.) }\end{array}$} \\
\cline { 2 - 7 } & $\begin{array}{c}\text { Soil } \\
\text { Culture }\end{array}$ & $\begin{array}{c}\text { Hydro. } \\
\text { Culture }\end{array}$ & $\begin{array}{c}\text { Soil } \\
\text { Culture }\end{array}$ & $\begin{array}{c}\text { Hydro. } \\
\text { Culture }\end{array}$ & $\begin{array}{c}\text { Soil } \\
\text { Culture }\end{array}$ & $\begin{array}{c}\text { Hydro. } \\
\text { Culture }\end{array}$ \\
\hline $\begin{array}{l}\text { Microsorum } \\
\text { membranaceum }\end{array}$ & $8.14 \pm 0.8$ & $12.40 \pm 0.6$ & $10.06 \pm 0.3$ & $11.80 \pm 0.7$ & $18.20 \pm 0.5$ & $24.20 \pm 0.3$ \\
\hline Asplenium nidus & $10.42 \pm 0.5$ & $14.90 \pm 0.7$ & $5.49 \pm 1.3$ & $5.50 \pm 0.9$ & $15.91 \pm 1.4$ & $20.40 \pm 0.9$ \\
\hline Nephrolepis exaltata & $6.07 \pm 1.6$ & $7.82 \pm 0.9$ & $7.94 \pm 0.1$ & $13.88 \pm 1.4$ & $14.01 \pm 0.9$ & $21.70 \pm 1.6$ \\
\hline Results are average of 10 replicates
\end{tabular}

Table 3. Comparative analysis of carotenoid content ( $\mathrm{mg} / \mathrm{g}$ fresh wt.) of the sporophytic plant parts (Lichtenthaler 1987)

\begin{tabular}{|l|c|c|c|c|c|c|}
\hline \multirow{2}{*}{$\begin{array}{c}\text { Plant } \\
\text { Parts used }\end{array}$} & \multicolumn{2}{c|}{$\begin{array}{c}\text { Microsorum } \\
\text { membranaceum }\end{array}$} & \multicolumn{2}{c|}{$\begin{array}{c}\text { Asplenium nidus } \\
\text { Nephrolepis } \\
\text { exaltata }\end{array}$} \\
\cline { 2 - 7 } & $\begin{array}{c}\text { Soil } \\
\text { Culture }\end{array}$ & $\begin{array}{c}\text { Hydro. } \\
\text { Culture }\end{array}$ & $\begin{array}{c}\text { Soil } \\
\text { Culture }\end{array}$ & $\begin{array}{c}\text { Hydro. } \\
\text { Culture }\end{array}$ & $\begin{array}{c}\text { Soil } \\
\text { Culture }\end{array}$ & $\begin{array}{c}\text { Hydro. } \\
\text { Culture }\end{array}$ \\
\hline Immature lamina & 4.36 & 6.82 & 4.86 & 5.23 & 3.96 & 4.87 \\
\hline Mature fertile lamina & 3.98 & 4.95 & 4.67 & 5.12 & 3.88 & 4.67 \\
\hline Young fertile lamina & 3.60 & 4.21 & 4.59 & 4.92 & 3.96 & 4.81 \\
\hline Rhizome & 0.92 & 1.41 & 0.63 & 1.18 & 0.72 & 1.23 \\
\hline Rachis & 0.32 & 1.23 & 0.53 & 0.91 & 0.48 & 1.05 \\
\hline \multicolumn{7}{|l|}{ Results are average of 10 replicates } \\
\hline
\end{tabular}

Table 4. Proline contents (mg/g fresh wt.) of the sporophytic plant parts (Bates et al. 1973)

\begin{tabular}{|l|c|c|c|c|c|c|}
\hline \multirow{2}{*}{$\begin{array}{c}\text { Plant } \\
\text { Parts used }\end{array}$} & \multicolumn{2}{c|}{$\begin{array}{c}\text { Microsorum } \\
\text { membranaceum }\end{array}$} & \multicolumn{2}{c|}{$\begin{array}{c}\text { Asplenium nidus } \\
\text { Nephrolepis exaltata }\end{array}$} \\
\cline { 2 - 7 } & $\begin{array}{c}\text { Soil } \\
\text { Culture }\end{array}$ & $\begin{array}{c}\text { Hydro. } \\
\text { Culture }\end{array}$ & $\begin{array}{c}\text { Soil } \\
\text { Culture }\end{array}$ & $\begin{array}{c}\text { Hydro. } \\
\text { Culture }\end{array}$ & $\begin{array}{c}\text { Soil } \\
\text { Culture }\end{array}$ & $\begin{array}{c}\text { Hydro. } \\
\text { Culture }\end{array}$ \\
\hline Immature lamina & 4.36 & 3.02 & 4.58 & 2.96 & 4.55 & 2.57 \\
\hline Mature fertile lamina & 6.05 & 5.88 & 7.86 & 6.21 & 7.01 & 5.82 \\
\hline Young fertile lamina & 6.33 & 4.06 & 5.88 & 3.97 & 6.68 & 4.02 \\
\hline Rhizome & 6.18 & 4.62 & 8.52 & 6.01 & 7.81 & 6.03 \\
\hline Rachis & 4.98 & 3.18 & 4.88 & 3.07 & 5.01 & 3.86 \\
\hline Results are average of 10 replicates & & & & & \\
\hline
\end{tabular}



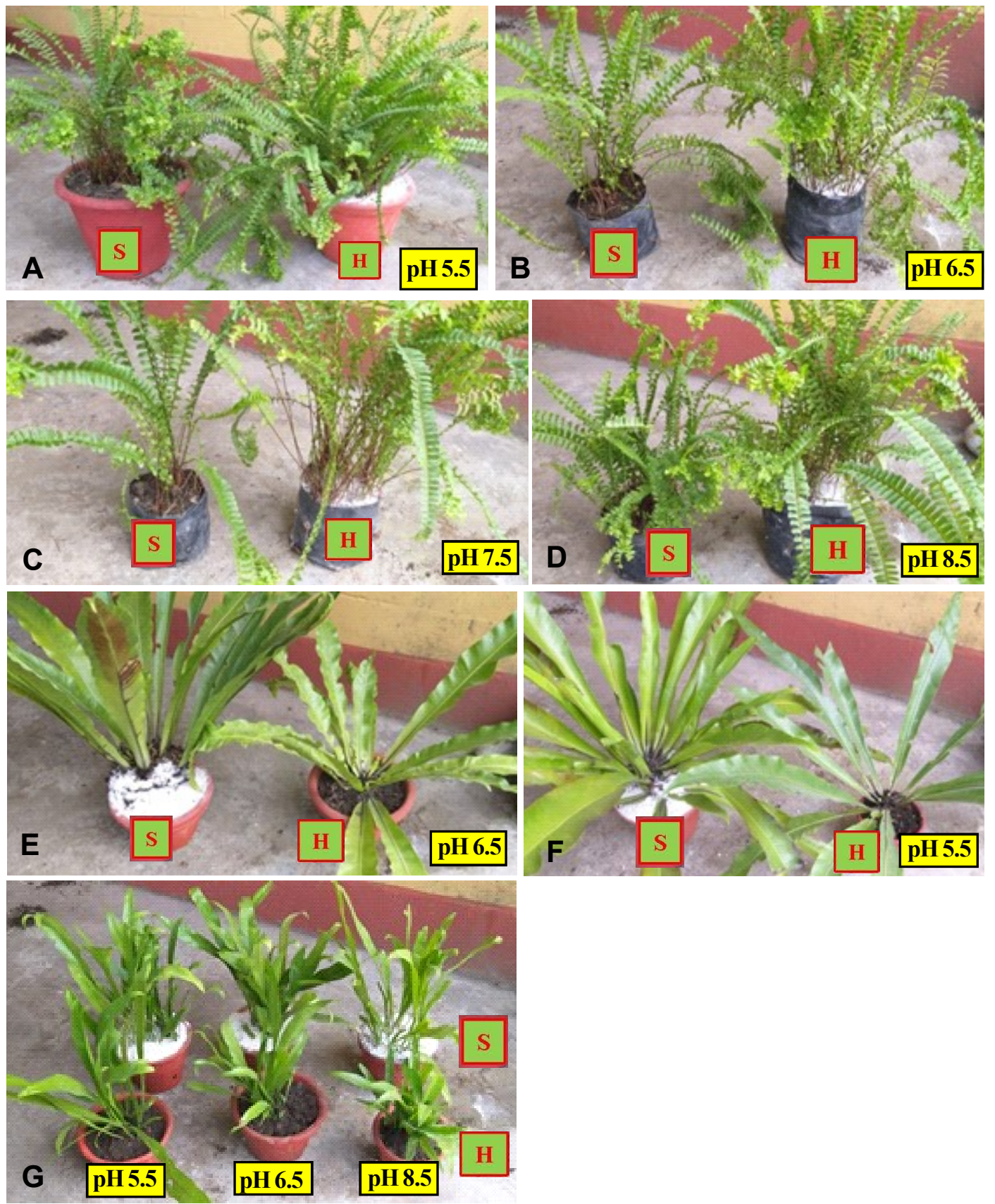

PLATE - III. Differential growth of test plants grown in hydroponics and in soil at different pH levels for: A - D: Nephrolepis membranaceum; E - F: Asplenium nidus; G: Microsorum exaltata.

[H: Hydroponically (perlite mix) grown; S: Soil grown] 
by the measurement of Proline contents (Table 4) which was much higher in soil grown plants than in hydroponically grown ones. The remarkable increase of proline content in soil grown plants is highly significant as proline is is known to increase under various stresses. Since all cultural conditions in the present study were kept identical except for the nutrients, the stress response could be presumed to be directly linked with nutrient stress faced by soil grown plants.

The $\mathrm{pH}$ of the nutrient media also played critical role in the growth and development of plants revealing different growth rates at different $\mathrm{pH}$ (Plate 3 ). The findings of dos Santos (2013) also revealed the importance of optimal nutrient medium and its uptake for the success of hydroponics. The findings of the present study, therefore, revealed that the success of hydroponic cultivation of ferns under Greenhouse conditions and their subsequent ex situ conservation was greatly influenced by optimization of the appropriate strength of the solution, duration of treatment followed by correct method of application.

\section{CONCLUSION}

The use of ex situ conservation techniques for endangered or threatened plants in germplasm banks has increased since its consideration in the Convention on Biological Diversity (UNEP 1992) and in the Global Strategy for Plant Conservation (UNEP 2002). It is widely employed for seed-bearing plants but needs further efforts in Pteridophytes. The results of the present study looks very promising for successful ex situ conservation of ferns but requires more field trials and optimization of growing conditions, lowering of infrastructural cost, skill development etc. Arcand and Ranker (2008) earlier reported that the success and application of new concepts like hydroponics for fern conservation requires multiple efforts of awareness and dissemination of scientific knowledge and skill in order to have a complete and balanced view of studies of pteridophyte for ex situ conservation and recovery programs.

\section{Acknowledgements}

The authors gratefully acknowledge the management and staff of the Department of Botany, Siliguri College and St. Joseph's College, Darjeeling for providing the infrastructural facilities and M/S Janak Nursery, Siliguri for providing the Greenhouse facilities for the present study.

\section{LITERATURE CITED}

Arcand, N.N. \& Ranker, T.A. 2008. Conservation biology. In:Ranker,T.A. \& Haufler,C.H. (eds.), Biology and Evolution of Ferns and Lycophytes, Cambridge University Press, Cambridge, UK.Pp. 257 - 283.

Arnon, D.I. 1949. Copper Enzymes in Isolated Chloroplasts. Polyphenoloxidase in Beta vulgaris. Plant Physiol. 24:1 - 15.

Bates, H.S.; Waldren, R.P. \& Treane, D. 1973. Rapid estimation of free proline for water stress determination. Plant Soil 39: $205-207$.

Fay, M.F. 1994. In what situations is in vitro culture appropriate to plant conservation? Biodiversity and Conservation 3: 176 - 183.

dos Santos, J. D. 2013. Development of a vinasse nutritive solution for hydroponics. Journal of Environmental Management. 114: 8 - 12.

Harbone, J.B. 1973. Phytochemical Methods. Chapman and Hall, London \&Toppan Company Limited, Tokyo, Japan. 
Hoagland, D.R. \& Arnon, D.I. 1950. The water-culture method for growing plants without soil. Berkeley California: College of Agriculture, University of California. [Reprinted from D.I. Arnon, Ed.] Pp. 1 - 31.

Johnson, M. 2003. In vitro studies on some rare and endangered ferns of Western Ghats, south India. Ph.D Thesis. Manonmanium Sundarnar University, Tamil Nadu, India.

Johnson, M.; Manickam, V.S. \& Irudayaraj, V. 2005. In vitro studies on the agamosporous fern (Pteris gongalensis T.G. Walker). Ethiop. J. Sci. Tech. 3(1): $1-8$.

Johnson, M. \& Manickam, V.S. 2006. In vitro studies on normal and abnormal life cycle of Metathelypteris flaccida (B1.) Ching. Ethiop. J. Sci. Tech. 4(1): 37 - 44.

Johnson, M. \& Manickam, V.S. 2007. Adventitious Proliferation of secondary and tertiary prothalli from the primary prothalli of Pronephrium articulatum (Houlst. \& Moore) Holt. Ethiop. J. Sci. Tech 3(2): 93 - 96.

Johnson, M.; Manickam, V.S.; Benniamin, A. \& Irudayaraj, V. 2008. Conservation of endangered ferns of Western Ghats through micropropagation. Indian Fern J. 28: $14-21$.

Lichtenthaler, I.I.K. 1987.Chlorophylls and carotenoids: pigments of photosynthetic biomembranes. Meth. Enzymol. 148: 350 - 382.

Manickam, V.S. 1995. Rare and endangered ferns of the Western Ghats of South India. Fern Gaz. 15: $1-10$.

Manickam, V.S.; Vallinayagam, S. \& Johnson, M. 2003. Micropropagation and Conservation of rare and endangered ferns of Western Ghats through in vitro culture. In: Chandra, S. \& Srivastava, M. (eds.). Pteridology in the New Millennium. Kluwer Academic Publishers, Netherlands. Pp: 497-504.

Marimuthu, J. \& Manickam, V.S. 2011. Ex situ conservation of two threatened ferns of the Western Ghats through in vitro spore culture. J. Threat. Taxa 3(7): 1919 - 1928.

Nair, L.G. 2000. Conservation through micropropagation restoration of selected woody medicinal plants. $\mathrm{PhD}$ Thesis. Kerala University, Thiruvananthapuram, Kerala, India.

Raven, P.H. 1999. World's biodiversity becoming extinct at levels rivaling earth's past "mass extinctions". Botanic Garden Conservation News 3: 31 - 32.

Sara, S.C. 2001. Conservation of selected rare and endangered ferns of the Western Ghats through micropropagation and restoration. PhD Thesis. Manonmaniam Sundaranar University, Tirunelveli, India.

Sara, C.S. \& Manickam, V.S. 2005. In vitro propagation of the critically endangered fern Cyathea crinita (Hook.) Copel. Asian J. Microb. Biotech. Env. Sci. 7: 527 - 536.

Sara, C.S. \& Manickam, V.S. 2007. In vitro developmental ontogeny and life cycle of a rare fern species - Thelypteris confluens (Thunb.) Morton. Indian J. Biotech. 6: $372-380$.

Sardare, M.D. \& Admane, S.V. 2013. A Review on Plant without Soil - Hydroponics. Intn. J. Res. Engin. Tech. 2(3): 299 - 304.

UNEP 1992: The Convention on Biological Diversity (CBD). www.cbd.int

UNEP: 2002: The Global Strategy for Plant Conservation (GSPC) with its 16 outcomeorientated targets aimed at achieving a series of measurable goals was adopted by the Conference of the Parties to the Convention on Biological Diversity (CBD) at its sixth meeting (COP-6) in 2002. https://www.unenvironment.org/ 